\title{
Socio-ecological competence as a significant component of a university graduate
}

\author{
Yuri Lobeyko ${ }^{1}$, Valentina Rodionova ${ }^{2}$, Valentine Ivashova ${ }^{3,}{ }^{*}$, Lyudmila Yengibaryan ${ }^{4}$, and \\ Suleya Barazbieva $^{5}$ \\ ${ }^{1}$ North Caucasus Federal University, 1, Pushkin Str., 355017, Stavropol, Russia \\ ${ }^{2}$ Institute of Services Industry and Business - Branch of the Don State Technical University in \\ Shakhty, 147, Shevchenko Str., 346500, Shakhty, Russia \\ ${ }^{3}$ Stavropol State Agrarian University, 12, Zootekhnichesky Lane, 355017, Stavropol, Russia \\ ${ }^{4}$ Armavir State Pedagogical University, 159, R. Luxenburg Str., 352901, Armavir, Russia \\ ${ }^{5}$ Kabardino-Balkar State University named after Kh.M. Berbekov, 173, Chernyshevsky Str., 360004, \\ Nalchik, Russia
}

\begin{abstract}
The article presents the results of studying the opinions of experts from the South of Russia about the demanded social and environmental competencies of graduates of higher education programs. An expert assessment of the competence profile of graduates was attended by 27 environmental specialists: municipal, state, supervisory management bodies that are engaged in environmental protection or environmental control. A comparative analysis of the actual labor functions indicated by experts and an assessment of the competencies of graduates in accordance with the Federal State Educational Standard showed the points of growth of the professional skills of future ecologists. Current trends (based on the review of publications) in the scientific discussion on the training of environmental specialists have been shown. The directions of improvement are formulated that are relevant for the training of ecologists in the South of Russia.
\end{abstract}

\section{Introduction}

One of the five national development goals of the Russian Federation for the period up to 2030 proclaimed a comfortable and safe environment for life. Achievement of this goal is impossible without increasing the socio-ecological competence of the population and, first of all, young generations who are entering into active professional activity. For university programs, the Federal State Educational Standard of Higher Education determines the basic level of social and environmental competence of graduates. At the same time, the leading teams, possessing knowledge, the most informed in this field are graduates of the university educational program "Ecology and Nature Management".

Experts in the field of ecology and nature management, possessing knowledge of the theoretical foundations of general ecology, geo-ecology, human ecology, social ecology,

\footnotetext{
*Corresponding author: vivashov@mail.ru
} 
environmental protection, applied ecology, in their professional activities determine the choice of environmental technologies, modern methods of environmental protection.

Specialists in ecology and nature management are responsible for:

- $\quad$ carrying out ecological expertise and monitoring, creating and maintaining ecological databases;

- $\quad$ forming the environmental policy of the enterprise;

- $\quad$ preparing programs and action plans for the implementation of environmental legislation;

- $\quad$ preparing environmental reports;

- $\quad$ performing calculations of expected noise levels in adjacent territories and in standardized premises;

- $\quad$ introducing and maintaining a system of internal environmental audit, a management system in the field of environmental protection.

Thus, we can speak, on the one hand, of the need to improve the quality of their training; on the other hand, the implementation of their production functionality should be associated with a high level of social responsibility. In this case, this is due to informing society about environmental problems and environmental protection measures, involving stakeholders in their development, increasing the social and environmental competence of both the management and specialists of enterprises and organizations, and representatives of the local community. We are analyzing the issue of the readiness of future graduates for that kind of activity.

\section{Materials and methods}

The empirical part of the study of the socio-ecological competence of graduates of the university programs was organized in the form of an expert survey of existing specialists in the field of ecology and nature management in the South of Russia. The time period for collecting primary sociological information was limited to two weeks. The survey was carried out in November 2020 using a questionnaire method with Google Forms. In total, 27 people took part in it from among the main and leading specialists in the field of ecology and nature management of such organizations as the Ministry of Natural Resources and Environmental Protection of the Stavropol Territory, the Center for Laboratory Analysis and Technical Measurements for the Southern Federal District and its branch in the Stavropol Territory, LLC "Ecological Guide" and etc. The data obtained during the expert survey were processed in the SPSS Statistics program (version 21) and presented in a generalized form of statistical distributions. The research toolkit included 53 questions, they were combined in information sections: assessment of the relevance of socio-environmental competencies defined in the current FSES; an informational review of the competencies necessary for experts to successfully fulfill their functional duties in the subject area "Ecology and Nature Management"; assessment of the social and environmental competence of environmental programs graduates of the university and the professional and qualification characteristics of the participants in the expert survey.

\section{Results}

Within the framework of the expert survey, specialists assessed the competencies of the current Federal State Educational Standard in the educational program "Ecology and Nature Management" at the Master's level. According to experts, the most significant are such competencies as - the ability to use modern methods of processing and interpreting 
environmental information in scientific and industrial research (26 out of 27 experts put it in the first place in terms of relevance). Next is such competence as the ability to use regulatory documents governing the organization of industrial and technological environmental work and methodologically competently develop an action plan for environmental audit, monitoring compliance with environmental requirements, and environmental management of production processes (the second place in terms of relevance by 23 experts out of 27 experts). Next 3 competencies experts identified approximately equally: the ability to develop standard environmental protection measures and assess the impact of planned structures or other forms of economic activity on the environment; the ability to use in-depth knowledge of legal and ethical norms in assessing the consequences of their professional activities, the development and implementation of socially significant projects, implementation $n$ practice the skills and abilities in the organization of research and scientific-production work in the management of the scientific team; the ability to apply modern computer technologies in collecting, storing, processing, analyzing and transmitting information to solve research and production problems in the field of ecology and nature management.

Thus, in the opinion of the expert community, the list includes competencies that are associated with the professional knowledge of information, factual and methodological base, it gives an understanding of production processes and their impact on the ecology and natural resource use of the territory. It is important to emphasize in the process of training modern specialists the regulatory and legal boundaries that are established by legislation to ensure environmental protection measures and protect the environment. Moreover, the deep motive in the application of knowledge in the field of ecology and nature management should be the social responsibility of a specialist, as his most important professional attribute. That, in general, allows us to speak about the importance of the social and environmental competence of modern graduates of the university programs. Environmental competence cannot be considered in isolation from the social responsibility of the personality of a specialist for professional actions in front of society, since it is ultimately aimed at the preservation and sustainable development of society in the broadest sense and the local community of the local territory.

Among the experts' own functionality, which is implemented as part of their job duties, there are the following activities:

- federal state supervision in the field of protection and use;

- development and submission of proposals for improving the regulatory and legal framework in the environmental sphere;

- development of measures to improve environmental protection based on the study and generalization of the best practices of domestic and foreign enterprises;

- signing the contracts in the field of nature management and environmental protection; development of the environmental policy of the enterprise;

- development of projects of long-term and current plans for environmental protection;

- control over the observance of the current environmental legislation in the divisions of the enterprise.

A review of the listed functional responsibilities, even if we take into account that not all, but the most relevant production tasks are indicated, shows that they do not include the promotion of social and environmental competencies to stakeholders: the population, management, specialists and employees of enterprises and organizations.

In the course of the survey, experts assessed the general professional competencies formed in graduates of the university educational programs "Ecology and Nature Management" and "Plant Protection". Comparative data are shown in the following table 1. 
Table 1. Expert assessment of the formation of general professional competencies.

\begin{tabular}{|c|c|c|}
\hline \multirow[b]{2}{*}{ Name of general professional competencies } & \multicolumn{2}{|c|}{ Graduates of the program } \\
\hline & \begin{tabular}{|c|} 
Ecology and Nature \\
Management
\end{tabular} & $\begin{array}{c}\text { Plant } \\
\text { Protection }\end{array}$ \\
\hline 1. Ability to set professional goals and objectives & 4.3 & 4.2 \\
\hline 2. Ability to highlight probable problems at work & 3.7 & 4.0 \\
\hline $\begin{array}{l}\text { 3. Ability to develop solutions and evaluate their } \\
\text { effectiveness }\end{array}$ & 3.8 & 4.2 \\
\hline $\begin{array}{l}\text { 4. Readiness for independent professional activity based } \\
\text { on an ecological worldview }\end{array}$ & 3.9 & 4.1 \\
\hline 5. Ability to use modern technical equipment & 4.0 & 4.7 \\
\hline $\begin{array}{l}\text { 6. Ability to independently obtain and interpret the } \\
\text { necessary information }\end{array}$ & 4.3 & 4.2 \\
\hline 7. Ability to plan your career & 3.0 & 3.3 \\
\hline 8. Ability to organize yourself and others & 3.8 & 3.8 \\
\hline 9. Positive attitude towards change & 3.5 & 3.8 \\
\hline 10. Ability to take criticism positively & 3.5 & 3.8 \\
\hline 11. Ability to learn & 4.3 & 4.3 \\
\hline
\end{tabular}

Comparative data indicate that, on average, the level of formation of general professional competencies of graduates of "Plant Protection" program is slightly higher than that of graduates of "Ecology and Nature Management" program. Including when it comes to readiness for independent professional activity based on an ecological worldview. In our opinion, this is explained by the more specific subject of work of Plant Protection specialists, who ensure the protection of plants from diseases and pests, taking into account the minimization of harm to humans and nature. Substantially, such activity reflects the graduate's readiness to show an ecological worldview.

The results of the survey of future ecologists show that the level of awareness of the national projects of the Russian Federation is high, including for the "Ecology" project.

At the same time, satisfaction with the quality of implementation of the "Ecology" project shows areas for improvement of this activity among the evaluations of the other 12 projects. $18.6 \%$ of respondents are fully satisfied with the quality of implementation of the "Ecology" project; rather satisfied than not $-12.4 \%$ of respondents; rather not satisfied $37.3 \%$ of respondents; not satisfied $-15.1 \%$ of respondents and found it difficult to give a definite answer $-16.6 \%$ of respondents.

Therefore, the promotion of social and environmental competence, both at the level of specialists - university graduates, and for the population, remains an urgent task of the state.

\section{Discussion}

Various aspects of socio-ecological competence are the subject of discussion by the international scientific community. Generalization of the key trends in scientific discussion makes it possible to use world experience in training specialists not only in environmental programs, but also to supplement substantively the systemic general professional competence of graduates of university programs in other areas of training.

Scientists M.E. OrduñaAlegría, N. Schütze, S.C. Zipper draw the attention of interested parties to the issues of social and ecological adaptation due to the limited water resources, including for agricultural needs [1]. The authors propose a game educational format for increasing the socio-ecological competence of the population and specialists. During the study of the results of the game sessions, important decision-making factors on the use of 
water resources in agriculture were identified. Among them were named: communication, trust, and socio-ecological competence. Thus, the development of social and environmental competence of both the population as a whole and the professional community of specialists in the agricultural sector is an important topic of research and implementation in the educational content of colleges and universities [2].

The importance of systemic competence as a result of modern education is considered by the authors of R. Mehren, A. Rempfler, J. Buchholz, J. Hartig, E.M. Ulrich-Riedhammer [3]. In the process of development and empirical verification of the factor model, natural, social systems and systems of man and the environment are called its actual components. Thus, systemic competence necessarily includes both awareness in the social sphere and in the field of the environment, it is associated with knowledge of issues of ecology and nature management [4].

The authors C. Aguayo, C. Eames, participating in the discussion of the issues of socioecological competence of modern society, in their article emphasize the importance of training the community for the implementation of social changes towards environmental sustainability [5]. Scientists have assessed the potential of information and communication technologies to improve the environmental literacy of the population of local areas and the ability of the local community to resolve social and environmental problems.

In the study of the transition of young people in England from education to work, the authors I. Schoon, M. Lyons-Amos suggest using the socio-ecological model of the employment agency [6]. The main goal is to provide assistance to such categories of young people who have an obvious lack of socio-economic and psychosocial resources. The authors of the study come to the conclusion that the transformation of educational potential into successful employment has as a result an increase in satisfaction with the life and competence of young people. Thus, the socio-ecological model of supporting youth employment increases the professional competence of college graduates and can be useful in supplementing the content of educational programs [7].

Article by authors V.S. Shilova, V.B. Tarabaeva, N.L. Shechovska, M.S. Zhirov, S.I. Tarasova is devoted to the socio-ecological competence of the student's personality [8]. Environmental competence is a set of interrelated personality traits (knowledge, skills, and abilities) required for the implementation of various types of practical activities from the standpoint of its environmental feasibility, including productive environmental protection activities. The authors define the peculiarities of studying the conditions for the formation of ecological and socio-ecological competence in university programs in accordance with the current Federal State Educational Standard. To study the current profile of a graduate of the university program from the point of view of socio-ecological competence, an articulated connection with ecological feasibility and environmental protection is of great importance.

The authors of the publication M.R. Freitas, R.L.G. Macedo, M.P. Freitas, C.A. Nunes, $\mathrm{N}$. Venturin propose to develop educational methods of diagnostics and increase the level of environmental competence. They tested the diagnostic method using the example of assessing the perception of the environment by the university community [9]. In the methodology, represented by 4 levels of complexity, the study participants assessed socioecological situations and identified possible scenarios for their resolution. In most cases, it turned out that the level of development of socio-ecological competence was not sufficiently high, which provides information on the areas of its development for the construction of the required level and re-diagnostics of learning outcomes. The authors emphasize the importance of the proposed approach not only for the university community, but also for the general population. This is because to ensure the sustainable development of territories, the relevance of socio-ecological competence increases and, accordingly, educational strategies for diagnostics and management of these processes are in demand. 
Research by K. Ontong, L.L. Grange shows an insufficient level of attention to sustainable development issues, which is modeled mainly through policies. According to the authors, it is important at all stages of education to form the need for sustainable development as a way of thinking of students and the formation of correct relationships with nature [10]. Thus, the foundations of socio-ecological competence should be laid at an early age in the system of public education and training. For our study, an important conclusion is that to ensure the socio-ecological competence of the university graduates, the foundation laid in the previous stages of education is necessary. The success of the implementation of this competence in professional activity depends, among other things, on the general readiness of society for socially responsible actions in the field of ecology and nature management at the level of daily practices $[11,12,13]$.

\section{Conclusion}

The conducted theoretical analysis of scientific sources, the empirical results of the study of the socio-ecological competence of graduates of the university program "Ecology and Nature Management" led to a number of conclusions:

1. To increase the social and environmental competence of the graduates of the program, it is necessary to supplement the profile with the skills of informing society about environmental problems and environmental protection measures, involving stakeholders in their development, increasing the social and environmental competence of management, specialists of enterprises and organizations, and representatives of the local community. It is important to ensure the readiness of future graduates for such activities.

2. To ensure the social and environmental competence of graduates of the university programs, the foundation laid in the previous stages of education is important. This position is consistent with ensuring sustainable development of territories and the demand for educational strategies for diagnosing socio-ecological competence in managing these processes at the level of individual territories.

3. The socio-ecological model of support for youth employment increases the professional competence of graduates and can be useful in supplementing the content of educational programs.

4. Information and communication technologies have a significant potential for increasing the environmental literacy of the population of local territories and the ability of the local community to resolve social and environmental problems.

5. The factor model of systemic competence of a graduate of a university program includes actual knowledge in natural, social, human and environmental systems. Thus, systemic competence necessarily includes awareness in the social sphere and in the field of the environment, which is associated with knowledge of issues of ecology and nature management.

6. In the course of the empirical part of the study, it was found that among the listed duties, experts working in the field of ecology and nature management do not name the promotion of social and environmental competencies to stakeholders: the population, management, specialists and employees of enterprises and organizations. The established contradiction is an area for improvement of this activity.

\section{References}

1. M.E. OrduñaAlegría, N. Schütze, S.C. Zipper, Sustainability (Switzerland) 12(13), $5301(2020)$ 
2. L. Filimonyuk, Y. Lobeyko, V. Ivashova, R. Chvalun, A. Kalashova, E3S Web of Conferences 203, 05021 (2020)

3. R. Mehren, A. Rempfler, J. Buchholz, J. Hartig, E.M. Ulrich-Riedhammer, Journal of Research in Science Teaching 55(5), 685-711 (2018)

4. P. Gradinger, D. Strohmeier, Reducing Cyberbullying in Schools: International Evidence-Based Best Practices, 189-202 (2018)

5. C. Aguayo, C. Eames, International Review of Education 63(6), 871-895 (2017)

6. I. Schoon, M. Lyons-Amos, Longitudinal and Life Course Studies 8(1), 35-56 (2017)

7. V.A. Ivashova, V.A. Burlyaeva, I.V. Yushchenko, R.V. Chvalun, O.V. SimenSeverskaya, E3S Web of Conferences 224, 04039 (2020)

8. V.S. Shilova, V.B. Tarabaeva, N.L. Shechovska, M.S. Zhirov, S.I. Tarasova, Social Sciences (Pakistan) 11(10), 2429-2433 (2016)

9. M.R. Freitas, R.L.G. Macedo, M.P. Freitas, C.A. Nunes, N. Venturin, Journal of Agricultural Education and Extension 21(2), 149-158 (2015)

10. K. Ontong, L.L. Grange, TydskrifvirGeesteswetenskappe 55(1), 50-61 (2015)

11. J. Devís-Devís, V.J. Beltrán-Carrillo, C. Peiró-Velert, Sport, Education and Society 20(3), 361-380 (2015)

12. M.R. Freitas, S.V.B.G. Matias, R.L.G. Macedo, N. Venturin, Chinese Journal of Population Resources and Environment 11(4), 352-356 (2013)

13. K.E. Cohen, P.J. Morgan, R.C. Plotnikoff, R.M. Hulteen, D.R. Lubans, Psychology of Sport and Exercise 32, 1-11 (2017) 